\title{
Zbiórki publiczne na rzecz Kościoła rzymskokatolickiego w świetle polityki wyznaniowej władz okresu gomułkowskiego
}

\begin{abstract}
Summary
Władysław Gomułka was the First Secretary of the Communist Party in Poland between 1956 and 1970. There was a strong conflict between State and Catholic Church in these times. The Church was prosecuted and one of the elements of this prosecutions referred to public collection of money, which was forbidden outside churches. Persons who tried to collect money were sentenced by the administration and money was confiscated. Later the Church has developed more efficient ways of illegal collections and was successful in hiding the incomes coming from this source. The Church prepared big celebrations of 1000 years of Polish Christianity in 1966. It was the biggest success of the Church in the 1960s.
\end{abstract}

1. Rządy Władysława Gomułki jako I Sekretarza KC PZPR cechowało zaostrzenie stosunków na linii państwo-Kościół. Odbudowie pozycji Kościoła w społeczeństwie, osłabionej wskutek represyjnej polityki władz okresu stalinowskiego ${ }^{1}$, służyło zainicjowanie przez prymasa Wyszyńskiego programu Wielkiej Nowenny ${ }^{2}$. Założeniem Wielkiej Nowenny było przygotowanie

${ }^{1}$ Bogaty spis literatury dotyczącej stosunków państwo-Kościół, w tym opracowań dotyczących represji wobec duchowieństwa w okresie stalinowskim, przedstawia J. Myszor w artykule Portret zbiorowy duchowieństwa represjonowanego w PRL (1944/45-1989), [w:] Represje wobec duchowieństwa kościołów chrześcijańskich w okresie stalinowskim w krajach byłego bloku wschodniego, J. Myszor, A. Dziurok (red.), Katowice 2004.

${ }^{2}$ Realizacja tego programu rozpoczęła się odnowieniem Ślubów Narodu na Jasnej Górze 26 sierpnia 1956 r., według zasad ściśle określonych przez przebywającego jeszcze w internowaniu prymasa. 
wiernych do obchodów Millenium Chrztu Polski poprzez organizowanie ogólnopaństwowych uroczystości religijnych, prowadzenie duszpasterstwa stanowego oraz pielgrzymki i procesje. Działaniom tym towarzyszył rozwój budownictwa sakralnego oraz przekształcenie lokalnych ośrodków kultu maryjnego $\mathrm{w}$ ogólnopolskie miejsca pielgrzymkowe ${ }^{3}$. Potrzeby materialne, związane z realizacją zadań Wielkiej Nowenny, wymagały odwołania się do ofiarności wiernych i pozyskiwania funduszy w drodze organizowania zbiórek publicznych na cele religijne.

Obowiązująca w Polsce Ludowej przedwojenna ustawa o zbiórkach publicz$n y c h{ }^{4}$ przewidywała wymóg uzyskania zezwolenia na wszelkie publiczne zbieranie ofiar $\mathrm{w}$ gotówce lub $\mathrm{w}$ naturze na pewien $\mathrm{z}$ góry określony cel, $\mathrm{w}$ tym także na cele religijne ${ }^{5}$. Pozwolenia na organizowanie zbiórek publicznych wydawały organy spraw wewnętrznych prezydiów rad narodowych ${ }^{6}$. Obowiązek uzyskania zezwolenia nie dotyczył zbiórek na cele religijne, prowadzonych w obrębie terenów kościelnych, gdyż zbiórki te były wyłączone spod zakresu obowiązywania ustawy. $\mathrm{W}$ przypadku prowadzenia zbiórek wbrew wymogom określonym w ustawie, przewidziane były sankcje karno-administracyjne: kara aresztu w wymiarze do 1 miesiąca oraz grzywna do $1500 \mathrm{zl}^{7}$, orzekane razem lub osobno. Karalności podlegali zarówno organizatorzy, jak i osoby przeprowadzające zbiórkę ${ }^{8}$, przy czym ukaranie za prowadzenie zbiórki publicznej bez wymaganego pozwolenia oznaczało obligatoryjny przepadek zebranych ofiar9 .

W początkowym okresie rządów Gomułki nie stwarzano większych przeszkód dla organizowania zbiórek publicznych na cele religijne, co wynikało z liberalizacji polityki wyznaniowej władz, zapoczątkowanej w okresie odwilży październikowej. Wraz z opanowaniem kryzysu destalinizacyjnego w sze-

Pierwszy rok Wielkiej Nowenny zakończyło powtórzenie ślubów we wszystkich parafiach w Polsce 5 maja 1957 r. Każdy kolejny roczny etap posiadał swój temat wiodący, wokół którego koncentrowała się praca duszpasterska z wiernymi. A. Dudek, R. Gryz, Komuniści i Kościół w Polsce (1945-1989), Kraków 2006, s. 119.

${ }^{3}$ J. Zbudniewek, Prawodawstwo i praktyka władz centralnych i terenowych PRL $w$ zakresie kultu religijnego, „Chrześcijanin w Świecie” 1994, nr 1, s. 108-109.

${ }^{4}$ Ustawa z dnia 15 marca 1933 r. o zbiórkach publicznych (Dz. U. Nr 22, poz. 162).

${ }^{5}$ Ustawa o zbiórkach publicznych, „Notificationes” 1958, nr 7-8, s. 327.

${ }^{6} \mathrm{~W}$ przypadku zbiórek organizowanych na terenie powiatu, były to wydziały spraw wewnętrznych prezydiów powiatowych rad narodowych, jeżeli zasięg terytorialny zbiórki przekraczał teren powiatu, to właściwe były urzędy spraw wewnętrznych prezydiów wojewódzkich rad narodowych. Zbiórki publiczne, „Poradnik dla Kolegiów Orzekających” 1958, nr 5, s. 22.

${ }^{7}$ Art. 11 ustawy o zbiórkach publicznych.

${ }^{8}$ Oznaczało to, iż ukaranie osoby przeprowadzającej zbiórkę nie zwalniało od odpowiedzialności organizatorów zbiórki. Zbiórki publiczne, op. cit., s. 25.

${ }^{9}$ Odpowiedź Departamentu Społeczno-Administracyjnego MSW na skargę obywatela Franciszka Bieruta, Archiwum Akt Nowych (dalej: AAN), zespół akt Urząd do Spraw Wyznań (dalej: UdSW), sygnatura teczki 71/42, s. 138. 
regach partyjnych komuniści podjęli zakrojoną na szeroką skalę ofensywę antykościelną ${ }^{10}$. Wstępny plan działania, mający na celu ograniczenie wpływów Kościoła, został zatwierdzony przez Biuro Polityczne KC PZPR 28 czerwca 1957 r. $^{11}$ Pełna realizacja tego planu przy wykorzystaniu metod o charakterze administracyjnym rozpoczęła się wraz powołaniem w lipcu następnego roku specjalnego zespołu KC PZPR do spraw kleru, zajmującego się opracowywaniem kierunków działania władz na tzw. odcinku wyznaniowym ${ }^{12}$. Jednocześnie KC PZPR wystosował do egzekutyw terenowych organizacji partyjnych instrukcję zawierającą zasady polityki wyznaniowej państwa ${ }^{13}$. Instrukcja zapowiadała "położenie tamy ofensywie wojującego klerykalizmu"14 poprzez zwalczanie wszelkich form pracy duszpasterskiej wykraczających poza ramy tradycyjnych obrzędów religijnych oraz ograniczenie zakresu budownictwa sakralnego ${ }^{15}$. Jedną z metod walki z religią była restrykcyjna polityka w zakresie udzielania pozwoleń na przeprowadzanie zbiórek publicznych poza miejscami kultu religijnego, której założeniem było uderzenie w podstawy materialne funkcjonowania Kościoła. Urząd do Spraw Wyznań ${ }^{16}$ (UdSW) wystosował zalecenie do terenowego aparatu spraw wewnętrznych, żeby „bardzo rygorystycznie pilnować przestrzegania zasady: żadnych składek poza kościołem"17. Jednocześnie na łamach wydawanego przez MSW „Poradnika dla Kolegiów Orzekających” podkreślono fakt „wzmożonej inicjatywy organizowania zbiórek” w latach 1957-1958, na przeprowadzanie których częstokroć udzielano zezwoleń bez „analizy istotnej potrzeby i celowości zbiórek"18. Wprawdzie nie wskazano wprost, iż chodzi o zbiórki na cele religijne, ale świadczy o tym publikacja artykułu w momencie rozpoczęcia antykościelnej ofensywy władz. Poza tym trudno wskazać inną niż

${ }^{10}$ A. Dudek, O działaniach antykościelnych władz PRL w latach 1958-1966, „Chrześcijanin w Świecie" 1994, nr 1, s. 191-192.

${ }^{11}$ Wytyczne stanowiska partii w sprawie stosunków miedzy państwem a Kościołem. Załącznik do protokołu z posiedzenia Biura Politycznego KC PZPR z dnia 28 czerwca 1957 r., opr. A. Friszke, „Więź” 1997, nr 3, s. 132-157.

${ }^{12}$ A. Dudek, O działaniach, op. cit., s. 191.

${ }^{13}$ List KC PZPR $z$ lipca 1958 r. do egzekutyw komitetów wojewódzkich, powiatowych i miejskich PZPR, [w:] P. Raina, Stefan Kardynał Wyszyński Prymas Polski, t. 2, Londyn 1986, s. 223-242.

${ }^{14}$ Ibidem, s. 231.

${ }^{15}$ A. Dudek, R. Gryz, Komuniści, op. cit., s. 126.

${ }^{16}$ Urząd do Spraw Wyznań został utworzony w 1950 r. Zakres jego uprawnień określono bardzo ogólnie, gdyż miał on zajmować się realizacją polityki wyznaniowej państwa. Stosunki z Kościołem należały do kompetencji wydziału wyznania rzymskokatolickiego. W rzeczywistości zadania urzędu polegały na ingerencji w sprawy wewnętrzne związków wyznaniowych w celu wymuszenia oczekiwanych postaw i zachowań natury politycznej duchownych. M. Pietrzak, Prawo wyznaniowe, Warszawa 1993, s. 223.

${ }^{17}$ Notatka Urzędu do Spraw Wyznań z 1960 r.: sprawa lojalnego stosunku do państwa $i$ władzy, [w:] P. Raina, Kościół katolicki a państwo w świetle dokumentów, t. 2, lata 1960-1974, Poznań 1995, s. 41.

${ }^{18}$ Zbiórki publiczne, op. cit., s. 21. 
Kościół katolicki instytucję, której inicjatywa w zakresie organizowania zbiórek publicznych byłaby nie na rękę ówczesnym władzom. Zmiana polityki organów administracji znalazła swoje odbicie w wydawanym przez Kurię Metropolitalną w Krakowie czasopiśmie „Notificationes”. W drugiej połowie 1958 r. zamieszczono w nim aktualny tekst ustawy o zbiórkach publicznych ${ }^{19}$, z kolei dokonaną pod koniec tegoż roku nowelizację ustawy o orzecznictwie karno-administracyjnym ${ }^{20}$ przedstawiono $\mathrm{w}$ świetle postępowania $\mathrm{w}$ sprawie zbiórek publicznych ${ }^{21}$.

2. Sygnałem świadczącym o przyjęciu przez władze restrykcyjnej polityki w zakresie zbiórek publicznych na cele religijne była sprawa zbiórki ofiar na remont zabytkowej katedry w Łomży. Przyjęta na tle tej sprawy przez UdSW wykładnia postanowień ustawy o zbiórkach publicznych stanowiła zapowiedź interpretacji i praktycznego stosowania tejże ustawy w duchu antykościelnym. Opisywana zbiórka została zorganizowana w wykonaniu uchwały zebrania łomżyńskiego Zrzeszenia Prywatnego Handlu i Usług i miała miejsce w sklepach należących do osób obecnych na zebraniu ${ }^{22}$. Organizatorzy nie widzieli potrzeby występowania o zezwolenie, powołując się na fakt wyłączenia spod zakresu obowiązywania ustawy zbiórek prowadzonych w lokalach prywatnych wśród grona osób znajomych osobiście przeprowadzającym zbiórkę ${ }^{23}$. Odmienne spojrzenie na sprawę cechowało łomżyński wydział spraw wewnętrznych, który uznał zbiórkę na witraże i ołtarz do katedry łomżyńskiej za nielegalną ${ }^{24}$. Skutkiem tego było orzeczenie przez kolegium karno-administracyjne grzywien wobec organizatorów zbiórki oraz przepadku uzyskanych od ofiarodawców funduszy. Stanowisko organów terenowych poparł UdSW, którego zdaniem zbiórki na cele religijne podlegają zwolnieniu z obowiązku uzyskania zezwolenia jedynie $\mathrm{w}$ przypadku ich przeprowadzania $\mathrm{w}$ obrębie terenów kościelnych. Natomiast przewidziane przez ustawę zwolnienie, na które powoływali się organizatorzy łomżyńskiej zbiórki, miało zastosowanie jedynie do jedno-

${ }^{19}$ Ustawa o zbiórkach publicznych, op. cit., s. 326-327.

${ }^{20}$ Ustawa z dnia 15 grudnia 1951 r. o orzecznictwie karno-administracyjnym (Dz. U. $\mathrm{Nr} 66$, poz. 454) została znowelizowana ustawą $\mathrm{z}$ dnia 2 grudnia 1958 r. o zmianie ustawy z dnia 15 grudnia $1951 \mathrm{r}$. o orzecznictwie karno-administracyjnym (Dz. U. Nr 77, poz. 396).

${ }^{21}$ Zmiana w postępowaniu karno-administracyjnym w sprawie zbiórek, „Notificationes” 1959, nr 4-5, s. 131.

${ }^{22}$ Oświadczenie Genowefy Sułkowskiej w sprawie zbiórki na zabytkową Katedrę Łomżyńską, AAN UdSW 56/560, s. 2.

${ }^{23}$ Stanowił o tym art. 13 punkt c ustawy o zbiórkach publicznych.

${ }^{24}$ List Biskupa Łomżyńskiego do Pana Ministra dr. Jerzego Sztachelskiego Petnomocnika Rzadu do Spraw Stosunków z Kościołem z 15 grudnia 1958 r., AAN UdSW 56/560, s. 1. 
razowych, okolicznościowych zbiórek na doraźne cele ${ }^{25}$. Zdaniem UdSW, „zbiórka zorganizowana przez łomżyńskie Zrzeszenie Prywatnego Handlu i Usług miała charakter zbiórki publicznej, na co wskazuje jej zasięg oraz sposób jej przeprowadzania", wobec czego brak było podstaw do interwencji w sprawie zmiany decyzji wydanych przez terenowe władze państwowe"26.

Praktyka stosowania ustawy o zbiórkach publicznych w kierunku niekorzystnym dla Kościoła była kontynuowana. Wskazuje na to sporządzone przez Episkopat Polski opracowanie dotyczące sytuacji Kościoła w Polsce na początku 1961 r. Zawarto w nim stwierdzenie, iż „zbiórki ofiar na tradycyjne cele religijne (...) są przedmiotem postępowania karno-administracyjnego i ukarań księży oraz wiernych i konfiskaty zebranych sum" ${ }^{27}$. Były to m.in. zbiórki na kwiaty do Grobu Pańskiego, na remont ołtarza, na zakup dywanu w kościele, ofiary złożone podczas pogrzebu na zamówioną mszę świętą, czy też na remont budynku gospodarczego celem dostosowania do katechezy ${ }^{28}$. W początkowych latach okresu gomułkowskiego władze tolerowały fakt organizowania takich zbiórek poza terenami kościelnymi bez zezwolenia, chcąc $\mathrm{w}$ ten sposób zademonstrować przychylne nastawnie do tradycyjnych form działalności duszpasterskiej Kościoła. Wraz ze zmianą kierunku polityki wyznaniowej komunistów, terenowy aparat spraw wewnętrznych zaczął w sposób rygorystyczny przestrzegać zasady, iż wszelkie zbiórki na cele religijne, odbywające się poza obrębem kościołów, podlegają obowiązkowi uzyskania zezwolenia. Praktyczne stosowanie tej zasady stanowiło zaskoczenie dla duchownych i katolików świeckich przeprowadzających zbiórki, skutkiem czego była duża liczba wniosków o ukaranie w trybie karno-administracyjnym za zorganizowanie zbiórek publicznych bez wymaganego zezwolenia. Największą liczbę nielegalnych zbiórek wykryto w latach 1959-1960, kiedy to sporządzono w tych sprawach odpowiednio 2200 i 1733 wnioski o ukaranie ${ }^{29}$. Działanie z zaskoczenia w opinii MSW przyniosło oczekiwane rezultaty, gdyż umożliwiło uderzenie Kościoła „W najczulsze

${ }^{25}$ Tytułem przykładu UdSW wskazywał zbiórki zorganizowane z okazji imienin, przyjęcia weselnego oraz innych zebrań ściśle prywatnych na pomoc powodzianom wśród grona osób znajomych osobiście. Znajomość osobista miała oznaczać więzy towarzyskie, podczas gdy ofiarodawców łomżyńskiej zbiórki łączyły więzy natury zawodowej. Odpowiedź Urzędu do Spraw Wyznań na pismo Kurii Biskupiej Łomżyńskiej z dnia 15 XII 1958 r., AAN UdSW 56/560, s. 10.

${ }^{26}$ Ibidem.

${ }^{27}$ Sytuacja Kościoła rzymsko-katolickiego i stosunek Państwa do Kościoła rzymsko-katolickiego w Polsce Ludowej w początku 1961 roku, [w:] P. Raina, Stefan Kardynat, t. 2, op. cit., s. 439-440.

${ }^{28}$ Ibidem, s. 439.

${ }^{29}$ Informacja o przebiegu orzecznictwa karno-administracyjnego w sprawach o wykroczenia związane z działalnością kleru rzymsko-kat. w 1962 r. oraz w sprawie działalności punktów katechetycznych w IV kwartale 1962 r., Instytut Pamięci Narodowej Oddział w Warszawie - Biuro Udostępniania i Archiwizacji Dokumentów (dalej: IPN BUiAD), zespół akt Ministerstwo Spraw Wewnętrznych II (dalej: MSW II), sygnatura teczki 7615, s. 56. 
jego miejsce” poprzez przechwycenie „milionowych kwot, pochodzących z nielegalnych zbiórek, w stosunku do których kolegia orzekły przepadek" 30 .

Początek lat sześćdziesiątych przyniósłi stopniowy spadek liczby wykrytych nielegalnych zbiórek - do 824 w 1962 r. $^{31}$, co władze tłumaczyły „zdecydowanym przeciwdziałaniem - $\mathrm{w}$ poprzednich latach - ze strony organów ścigania oraz surowymi represjami stosowanymi przez kolegia"32. Należy przypuszczać, że przyczyna takiego stanu rzeczy tkwiła również w dostosowaniu się Kościoła do restrykcyjnej polityki władz i zmiany sposobu organizowania zbiórek, a zwłaszcza przechowywania uzyskanych ofiar. W sprawozdaniu MSW obejmującym 1961 r. stwierdzono bowiem, że polityka represyjna w omawianym zakresie „nie jest tak dotkliwa, przed wszystkim w stosunku do kleru, gdyż nie godzi jak to miało miejsce w 1959 r. i w 1960 r. - w najczulsze jego miejsce"33. Miało to wynikać z faktu, że „W ujawnionych nielegalnych zbiórkach publicznych zdołano zabezpieczyć z reguły tylko małe kwoty”, chociaż „organy powołane do ścigania tych wykroczeń stwierdzają autorytatywnie, że tylko tyle ofiar zdołano zabezpieczyć do momentu ujawnienia zbiórki”. Wprawdzie brak było odpowiednich dowodów obalających lub potwierdzających powyższą tezę, ale znaczny spadek wartości kwestionowanych ofiar pochodzących z nielegalnych zbiórek budził wątpliwości kierownictwa MSW ${ }^{34}$.

Zanotowany w 1961 r. spadek liczby wniosków o ukaranie wynikał także z niedoskonałości systemu wykrywania wykroczeń, gdyż organy MO nie były w stanie stwierdzić, czy „ilość skierowanych wniosków do kolegiów k-a odpowiada ilości faktycznie popełnionych przestępstw"35. Miały przy tym miejsce przypadki niewłaściwego ustalenia przez organy ścigania osób organizujących zbiórki publiczne, co prowadziło do wydawania przez kolegia orzeczeń uniewinniających ${ }^{36}$. Bezradność MO obrazuje sytuacja z powiatu Hrubieszów, gdzie pod oknami posterunku w Drohobyczu zorganizowano nielegalną zbiórkę publiczną, której sprawców nie wykryto ${ }^{37}$. Przeprowadzone z polecenia MSW kontrole wykazały ponadto „silne oddziaływanie środowiska kościelnego przy słabym jednocześnie politycznym przeciwdziałaniu podstawowych organizacji partyjnych, komend MO, prezydiów rad narodowych" na lokalny aparat milicji ${ }^{38}$.

\footnotetext{
${ }^{30}$ Informacja $z$ przebiegu orzecznictwa karno-administracyjnego w sprawach o wykroczenia związane $z$ działalnością kleru i aktywu przykościelnego, AAN UdSW 61/978, s. 8.

${ }^{31}$ Informacja o przebiegu orzecznictwa... w IV kwartale 1962 r., op. cit., s. 56.

${ }^{32}$ Informacja z przebiegu orzecznictwa, op. cit., s. 3.

${ }^{33}$ Ibidem, s. 8.

${ }^{34}$ Ibidem, s. 3.

${ }^{35}$ Ibidem, s. 4.

${ }^{36}$ Informacja o przebiegu orzecznictwa karno-administracyjnego w sprawach zwiazanych $z$ działalnością kleru rzymsko-kat. w III kwartale 1963 r., IPN BUiAD MSW II 7615, s. 114.

${ }^{37}$ Informacja z przebiegu orzecznictwa, op. cit., s. 4.

${ }^{38}$ Ibidem, s. 5.
} 
Analizując wyniki kontroli, MSW nakazało kierownictwu organów MO podjąć „bardziej zdecydowane środki, mające na celu wyeliminowanie wpływów środowisk klerykalnych na niektórych ich pracowników”. Za wskazaną uznano pomoc terenowych instancji partyjnych, które miały omówić w komendach $\mathrm{MO}$ „polityczną wagę” wykroczeń związanych z działalnością Kościoła oraz „sposoby zapobiegania im oraz środki zwalczania". Instancje partyjne miały ponadto „wpłynąć na funkcjonariuszów MO, zwłaszcza członków partii, aby sprawom tym poświęcali więcej uwagi”"

Uwagi MSW dotyczyły wprawdzie całokształtu ścigania wykroczeń związanych z „działalnością kleru i aktywu przykościelnego”, lecz w największym stopniu odnosiły się do nielegalnych zbiórek. Pod względem liczby sporządzonych w latach 1959-1962 wniosków o ukaranie pozostałe rodzaje wykroczeń zebrane łącznie dorównywały nielegalnym zbiórkom publicznym na cele religijne. Dane statystyczne z 1959 r. pokazują, iż z ogólnej liczby 3366 wniosków o ukaranie 2200 dotyczyło nielegalnych zbiórek, w 1961 r. proporcje te wynosiły 2592 i 1 252, natomiast w 1962 r. sporządzono łącznie 1460 wniosków, z czego w sprawach zbiórek $824^{40}$. Podobnie rzecz miała się w kolejnych latach; sprawozdanie z przebiegu orzecznictwa karno-administracyjnego w II kwartale 1963 r. zawiera stwierdzenie, iż „najliczniej występują w dalszym ciągu sprawy o nielegalne zbiórki publiczne na cele religijne lub na rzecz księży. Stanowią one $50 \%$ ogółu spraw" ${ }^{31}$.

Zakończenie akcji Wielkiej Nowenny pociągnęło za sobą pewne ograniczenie zakresu zbiórek na cele religijne, co znalazło swoje odbicie w statystykach obejmujących końcówkę lat sześćdziesiątych. O ile w ostatnim roku Wielkiej Nowenny organa ścigania wykryły 253 nielegalne zbiórki, to w 1967 r. liczba ta zmalała do 149. Oprócz mniejszego zakresu uroczystości kościelnych przyczyny takiego stanu rzeczy miały tkwić $\mathrm{w}$ „podjęciu określonych środków profilaktycznych $\mathrm{w}$ postaci rozmów ostrzegawczych $\mathrm{z}$ klerem i aktywem przykościelnym". Istotną rolę przypisywano także pracy politycznej organizacji partyjnych i organów spraw wewnętrznych wspieranych przez aktyw społeczno-polityczny „w środowiskach poddanych penetracji kleru”42. Optymistyczny ton powyższego sprawozdania zakłócał fakt nieskuteczności organów ścigania w przejmowaniu dochodów Kościoła pochodzących z nielegalnych zbiórek, gdyż w 1967 r. przeciętnie na każdą wykrytą zbiórkę zabezpieczono tylko 330 zł ${ }^{43}$.

${ }^{39}$ Ibidem, s. 14.

${ }^{40}$ Informacja o przebiegu orzecznictwa... w IV kwartale 1962 r., op. cit., s. 56.

${ }^{41}$ Informacja o przebiegu orzecznictwa karno-administracyjnego $w$ sprawach zwiazanych $z$ działalnością kleru rzymsko-kat. w II kwartale 1963 r., IPN BUiAD MSW II 7615, s. 92.

${ }^{42}$ Notatka dot. działalności kleru rzymsko-katolickiego w 1967 r., IPN BUiAD MSW II 7615, s. 15.

${ }^{43}$ Ibidem, s. 16. 
Skuteczne $\mathrm{z}$ reguły ukrywanie dochodów pochodzących ze zbiórek publicznych przed organami ścigania szło $\mathrm{w}$ parze $\mathrm{z}$ przyjmowaniem przez duchowieństwo niekonfrontacyjnej postawy wyrażającej się $\mathrm{w}$ unikaniu „wyraźnego naruszania obowiązujących przepisów prawa" ${ }^{4}$. Skutkowało to niewielką liczbą wykrytych przypadków organizowania zbiórek publicznych na cele religijne bez zezwolenia, a tym samym dalszym spadkiem liczby wniosków o ukaranie ${ }^{45}$. Sprawozdanie obejmujące 1970 r. zawierało wzmiankę, iż „W ostatnich latach notuje się dalszy spadek liczby wniosków o ukaranie"46, przy czym tradycyjnie „najwięcej wniosków o ukaranie dotyczyło nielegalnych zbiórek publicznych" ${ }^{47}$.

3. Antykościelna postawa władz w zakresie zbiórek publicznych na cele religijne przejawiała się także $\mathrm{w}$ restrykcyjnym podejściu do udzielania zezwoleń na organizowanie takich zbiórek. Rygorystyczne stosowanie do tradycyjnych zbiórek na cele religijne wymogów zawartych w ustawie o zbiórkach publicznych nie spowodowało masowego składania podań o wydanie zezwoleń. Wobec wrogiej Kościołowi postawy aparatu spraw wewnętrznych szanse na pozytywne rozpatrzenie wnoszonych przez duchowieństwo i katolików świeckich podań były bowiem niewielkie. Dane statystyczne wskazują, iż liczba składanych wniosków była stosunkowo mała, np. w I kwartale 1963 r. do organów spraw wewnętrznych wpłynęło 7 podań o „udzielenie zezwolenia na przeprowadzenie zbiórek publicznych związanych z działalnością kleru rzymskokatolickiego", z czego pozytywnie rozpatrzono tylko jedno. W tym samym czasie wykryto 52 nielegalne zbiórki, kierując do kolegiów karno-administracyjnych 108 wniosków o ukaranie ${ }^{48}$. Sprawozdania cyfrowe z poszczególnych województw wskazują na brak jakiejkolwiek inicjatywy w zakresie składania podań, przy jednoczesnym wykryciu przypadków nielegalnych zbiórek. Organy spraw wewnętrznych województwa krakowskiego w IV kwartale 1963 r. nie otrzymały

${ }^{44}$ Notatka dot. działalności kleru rzymsko-katolickiego w 1969 r., IPN BUiAD MSW II 7615, s. 140

${ }^{45}$ W 1969 r. wykryto 39 nielegalnych zbiórek, a w 1970 - 58. Liczba wniosków o ukaranie w sprawach nielegalnych zbiórek: 53 w 1969 r. i 74 w roku 1970. Notatka dot. działalności kleru rzymsko-katolickiego w 1970 r., IPN BUiAD MSW II 7615, 152.

${ }^{46}$ Przyczynić się do tego miały „przeprowadzane rozmowy profilaktyczne z księżmi, jak również fakt, iż kler coraz częściej unika wyraźnego naruszania obowiązujących przepisów prawa". Notatka dot. działalności... w 1970 r., op. cit., s. 152.

${ }^{47}$ Ibidem.

${ }^{48}$ Notatka w sprawie zgromadzeń i zbiórek publicznych za I kwartał 63 r., IPN BUiAD MSW II 7615, s. 76-77.

${ }^{49}$ Sprawozdanie cyfrowe $w$ sprawie zgromadzeń i zbiórek publicznych $z$ terenu województwa krakowskiego za okres IV kwartału 1963 r., IPN BUiAD MSW II 7623, s. 33. 
żadnego podania, chociaż wykryto 10 przypadków „zbiórek na cele religijne przeprowadzonych bez wymaganego zezwolenia" ${ }^{49}$. Z kolei sprawozdanie $\mathrm{z}$ terenu województwa warszawskiego obejmujące II kwartał 1964 r. zawiera wzmiankę o wydaniu pozwoleń na przeprowadzenie zbiórek „urządzanych przez miejscowe OSP na budowę lub dokończenie budowy remiz ewentualnie sprzęt strażacki" ${ }^{50}$. Brak jest $\mathrm{w}$ tym sprawozdaniu jakiejkolwiek wzmianki o podaniach dotyczących zbiórek publicznych na cele religijne, które oczywiście odbyły się bez zezwolenia w 13 przypadkach ${ }^{51}$. Podkreślić należy przy tym fakt wykrywania przez organy ścigania prawie wyłącznie nielegalnych zbiórek na potrzeby Kościoła - we wspomnianym sprawozdaniu cyfrowym $\mathrm{z}$ województwa krakowskiego było to 10 przypadków na $11^{52}$. Z kolei sprawozdanie dotyczące województwa warszawskiego mówi jedynie o nielegalnych zbiórkach na cele religijne ${ }^{53}$.

Druga połowa lat sześćdziesiątych nie przynosi istotnej zmiany stanowiska władz w zakresie wydawania zezwoleń, chociaż wraz z zakończeniem programu Wielkiej Nowenny następowało powolne odprężenie w napiętych stosunkach państwo-Kościól. Kontynuowanie restrykcyjnej polityki uzasadniano tym, że działalność „kleru prowadziła w wielu przypadkach do łamania obowiązujących przepisów prawa, szczególnie w zakresie (...) zbiórek publicznych" ${ }^{54}$. W sprawozdaniu obejmującym 1967 r. jest mowa o tym, że „do wydziałów spraw wewnętrznych wpłynęło 16 podań kleru o zezwolenie na przeprowadzenie zbiórek publicznych (w 1966 r. - 30), z czego załatwiono odmownie 9 podań (w 1966 r. - 13)" 55 . W kolejnych latach sytuacja nie uległa zmianie, gdyż „W 1970 r. do wydziałów spraw wewnętrznych wpłynęło 13 wniosków (w 1969 r. - 9) o wydanie zezwolenia na zbiórki publiczne. Pozytywnie załatwiono 5 wniosków (w 1969 r. - 2). W 58 przypadkach ujawniono nielegalne zbiórki (w 1969 r. - 39)" ${ }^{\prime \prime 6}$.

${ }^{50}$ Sprawozdanie opisowe ze zbiórek i zgromadzeń za II kwartał $1964 r$. Notatka sporządzona przez Urząd Spraw Wewnętrznych Prezydium Wojewódzkiej Rady Narodowej w Warszawie, IPN BUiAD MSW II 7638, s. 237.

${ }^{51}$ Ibidem.

${ }^{52}$ Sprawozdanie cyfrowe, op. cit., s. 33.

${ }^{53}$ Sprawozdanie opisowe... za II kwartat 1964 r., op. cit., s. 237.

${ }^{54}$ Notatka dot. działalności... w 1967 r., op. cit., s. 13.

${ }^{55}$ Ibidem, s. 15.

${ }^{56}$ Notatka dot. działalności... w 1970 r., op. cit., s. 152. 
4. Represja karno-administracyjna $\mathrm{w}$ sprawach o nielegalne zbiórki publiczne na cele religijne była skierowana głównie przeciwko katolikom świeckim ${ }^{57}$, na których spoczywał główny ciężar organizowania i prowadzenia zbiórek. Niewielki procent wniosków o ukaranie dotyczył bezpośrednio duchowieństwa, np. w 1960 r. na ogólną liczbę 1733 wniosków jedynie 194 sporząadzono przeciwko osobom duchownych ${ }^{58}$. Tendencja ta utrzymywała się w kolejnych latach; w 1962 r. sporządzono łącznie 824 wnioski o ukaranie, z czego jedynie 89 przypadało na księży ${ }^{59}$. Z kolei wykryte na terenie województwa krakowskiego w II kwartale 1964 r. nielegalne zbiórki z reguły „przeprowadzane były po wsiach przez osoby świeckie - kobiety lub mężczyzn ze środowiska wiejskiego, a tylko w dwóch przypadkach prowadzili je księża". Przeprowadzanie zbiórek pomimo karania przez kolegia ich organizatorów miało świadczyć „o dużym jeszcze oddziaływaniu kleru na ludność wiejską i dużej jej podatności na inspirację księży" ${ }^{\prime 0}$. Stosowana przez kolegia polityka karna opierała się na zasadzie indywidualizacji winy i kary, co w praktyce oznaczało surowe traktowanie przedstawicieli duchowieństwa jako grupy społecznej uważanej za nieprzychylną Polsce Ludowej. Łagodniej starano się podchodzić do osób świeckich, w przypadku których element represyjny nie odgrywał tak istotnej roli jak w przypadku duchownych.

W sprawozdaniu obejmującym 1961 r. podkreślono prawidłowe stosowanie przez kolegia zasady indywidualizacji winy i kary, podając jako przykład wymierzenie księdzu organizującemu zbiórkę publiczną bez zezwolenia grzywny w maksymalnym wymiarze $1500 \mathrm{zł}^{61}$. Dolegliwość finansowa tej kary była znaczna, gdyż jej wysokość odpowiadała przeciętnemu wynagrodzeniu w Polsce pierwszej połowy lat sześćdziesiątych ${ }^{62}$. Za podobne wykroczenie 75-letniemu „aktywiście świeckiemu, utrzymującemu się $\mathrm{z}$ alimentów płaconych przez

${ }^{57} \mathrm{~W}$ stosunku do katolików świeckich podejmowano także działania mające na celu odciągnięcie ich od przeprowadzania dozwolonych przez prawo zbiórek na cele religijne w obrębie kościołów. Zdaniem Episkopatu, „zbieranie składek na ofiarę w Kościele w czasie nabożeństw przez świeckich parafian spotyka się ze sprzeciwem władz państwowych, zbierający wzywani są do Prezydium Rady Narodowej i przestrzegani, by zaniechali”. Opracowanie władz kościelnych na temat sytuacji Kościoła rzymskokatolickiego i stosunku państwa do Kościoła w Polsce Ludowej (1961 r.), [w:] P. Raina, Kościót katolick a państwo, op. cit., s. 80.

${ }^{58}$ Informacja $z$ przebiegu orzecznictwa, op. cit., s. 2.

${ }^{59}$ Informacja o przebiegu orzecznictwa... w IV kwartale 1962 r., op. cit., s. 59.

${ }^{60}$ Sprawozdanie opisowe... za II kwartat 1964 r., op. cit., s. 237.

${ }^{61}$ „Kolegium powiatowe w Koninie za zorganizowanie zbiórki publicznej bez zezwolenia ukarało ks. Franciszka Bartczaka grzywną 1500 złotych”. Informacja z przebiegu orzecznictwa, op. cit., s. 6.

${ }^{62}$ Ustaleń tych dokonałem w oparciu o pochodzącą z 1963 r. notatkę dotyczącą postępowania karno-administracyjnego przeciwko uczestnikom nielegalnej pielgrzymki do Częstochowy. Obok wymierzonych przez kolegium przy Prezydium Powiatowej Rady Narodowej w Piasecznie i w Grójcu kar, notatka zawiera dane dotyczące zawodu i zarobków osób ukaranych. Zarobki ukaranych pracowników fizycznych kształtowały się w przedziale 800-1 500 zł, przedszkolanka zarabiała 700 zł, sprzątaczka - 
dzieci”"63 wymierzono jedynie karę nagany. W przypadku zbiórki organizowanej przez księdza w powiecie włodawskim, którą następnie przeprowadzały osoby świeckie wysokość kar grzywny była zróżnicowana. Maksymalny wymiar kary orzeczono wobec duchownego, natomiast łagodniej potraktowano pozostałych obwinionych $^{64}$. Także kary orzeczone wobec trzech staruszek organizujących bez zezwolenia zbiórki na terenie powiatu Kutno były stosunkowo niskie, gdyż ich wysokość wynosiła od 100 do $200 \mathrm{zz}^{65}$. Założenie kierowania ostrza represji karno-administracyjnej przeciwko duchownym było realizowane w kolejnych latach, na co wskazuje orzecznictwo kolegiów województwa warszawskiego w 1964 r. Zbiórka jaj kurzych na potrzeby kleryków seminarium duchownego przeprowadzona przez księdza podczas lekcji religii spotkała się z represją w postaci 1 000-złotowej grzywny, połączonej z konfiskatą zebranych 128 jaj. Natomiast gospodynie wiejskie zbierające jaja na potrzeby miejscowego kościoła zostały ukarane grzywną po 400 zł, chociaż zebrały większą ilość ofiar w naturze niż ukarany wysoką grzywną ksiądz ${ }^{66}$.

Od powyższej reguły zdarzały się oczywiście odstępstwa, ale miały one charakter jednorazowych przypadków warunkowanych szczególnymi okolicznościami sprawy. Kolegium w Otwocku ukarało w 1964 r. gospodynię wiejską zbierającą pieniądze na prezent dla księdza grzywną 1500 zł, co miało zrekompensować niemożność ustalenia przez organy ścigania zebranej kwoty i orzeczenia jej przepadku. Trudności z ustaleniem przeznaczenia zebranej kwoty oraz wysokości uzyskanych ofiar spowodowały ukaranie grzywną $\mathrm{w}$ maksymalnym wymiarze gospodarza $\mathrm{z}$ powiatu Przasnysz zbierającego pieniądze "rzekomo na budowę kościoła"67. Zdarzały się także przypadki wyjątkowo łagodnego traktowania księży organizujących bez zezwolenia zbiórki produktów żywnościowych. Księdzu zbierającemu jaja kurze na terenie powiatu siedleckiego w 1967 r. wymierzono jedynie naganę, ale brak dolegliwości finansowej tej kary rekompensował przepadek zebranych 2000 jaj ${ }^{68}$.

800, pielęgniarki od 1100 do 1 300, pracownicy umysłowi od 1200 do 2000 zł, planistka 1600, księgowa 1700 zł, wykwalifikowani pracownicy fizyczni w granicach od 2000 (stolarz) do 2700 zł (szkutnik). AAN UdSW 71/42, s. 188-189.

${ }^{63}$ Informacja z przebiegu orzecznictwa, op. cit., s. 6.

${ }^{64}$ „Kolegium powiatowe we Włodawie ukarało ks. Turskiego grzywną 1500 złotych oraz orzekło przepadek 16000 złotych pochodzących ze zbiórki publicznej. Ukarano ponadto 5 osób, które przeprowadzały zbiórkę grzywnami od 800 do 1200 złotych". Informacja z przebiegu orzecznictwa, op. cit., s. 7.

${ }^{65}$ Ibidem.

${ }^{66}$ Sprawozdanie opisowe... za II kwartał 1964 r., op. cit., s. 238-239.

${ }^{67}$ Ibidem, s. 238.

${ }^{68}$ Wykaz zastosowanych $w$ roku 1967 oraz $w$ roku 1968 kar w stosunku do osób duchownych i zakonnych za naruszenie obowiązujących przepisów prawnych na terenie woj. warszawskiego, AAN UdSW 83/11, s. 137. 
Podstawowa kara w sprawach o nielegalne zbiórki - kara grzywny - była zdaniem MSW stosunkowo niska $\mathrm{w}$ porównaniu $\mathrm{z}$ sankcjami przewidzianymi za innego rodzaju wykroczenia związane z działalnością Kościoła. Wprawdzie w 1961 r. skierowano do sejmu projekty nowych ustaw o zbiórkach publicznych $^{69}$ i o zgromadzeniach, które podnosiły maksymalną wysokość kary grzywny do 4500 zł, lecz jedynie w przypadku zgromadzeń projekt wszedł w życie. Przepisy dotyczące karalności nielegalnych zbiórek pozostały niezmienione, co zdaniem aparatu spraw wewnętrznych miało w poważnym stopniu utrudniać zwalczanie tych wykroczeń. Na tle kar wymierzanych w sprawach o nielegalne zgromadzenia oraz inne wykroczenia, które z reguły przekraczały $1000 \mathrm{zl}$, przeciętna wysokość grzywny za nielegalne zbiórki była znacznie niższa ${ }^{70}$. Przykładowo w 1962 r. średnia kara grzywny w sprawach o nielegalne zbiórki publiczne wynosiła $790 \mathrm{zł}$, w przypadku nielegalnych zgromadzeń była to kwota $1460 \mathrm{zl}$, natomiast $\mathrm{w}$ odniesieniu do wykroczeń związanych $\mathrm{z}$ budownictwem sakralnym $1520 \mathrm{z}^{71}$.

Stosunkowo niską maksymalną wysokość kary grzywny w sprawach o nielegalne zbiórki publiczne miało rekompensować orzekanie przepadku zebranych ofiar. Jak już wcześniej wspomniano, w latach 1959-1960 kolegia orzekły przepadek uprzednio zabezpieczonych przez organy ścigania „milionowych kwot pochodzących z nielegalnych zbiórek"72. Kolejne lata przyniosły znaczący spadek wartości kwot ulegających przepadkowi, które nie wyrażały się w milionach, lecz jedynie w setkach tysięcy złotych - w 1961 r. była to kwota około 541 tys. ${ }^{73}$, rok później jedynie 144 tys. ${ }^{74}$ Druga połowa lat sześćdziesiątych przyniosła przepadek kwot rzędu kilkudziesięciu tysięcy złotych rocznie, przykładowo w 1967 r. „kolegia orzekły przepadek zebranych ofiar tylko na kwotę 49 tys.”75. Z kolei w sprawozdaniach obejmujących ostatnie lata okresu gomułkowskiego

${ }^{69}$ Projekt ustawy spotkał się ze sprzeciwem Episkopatu, którego zdaniem „nie istnieje konieczność wydania nowej ustawy o zbiórkach publicznych". Episkopat podkreślał znaczne ograniczenie w projekcie dotychczasowych uprawnień w zakresie przeprowadzania zbiórek poprzez wyłączenie spod zakresu obowiązywania ustawy „zbiórek na cele kultu religijnego”, w miejsce dotychczasowych zbiórek „na cele religijne". List Sekretarza Episkopatu bp. Z. Choromańskiego do Rady Ministrów w sprawie ustawy o zbiórkach publicznych (3 lipca 1961 r.), [w:] P. Raina, Kościót katolicki a państwo, op. cit., s. 121.

70 „Kary grzywny do 1000 złotych wymierzone zostały przede wszystkim za przeprowadzanie zbiórek publicznych bez zezwolenia /zagrożenie do $1500 \mathrm{zł//".} \mathrm{Informacja} \mathrm{o} \mathrm{przebiegu} \mathrm{orzecznictwa...}$ w III kwartale 1963 r., op. cit., s. 82.

${ }^{71}$ Informacja o przebiegu orzecznictwa... w IV kwartale 1962 r., op. cit., s. 59.

${ }^{72}$ Informacja z przebiegu orzecznictwa, op. cit., s. 8.

${ }^{73}$ Instrukcja dyrektora Departamentu Społeczno-Administracyjnego MSW H. Chmielewskiego dla kierowników USW PWRN z 5 marca 1962 r., [w:] A. Dudek, Państwo i Kościót w Polsce w latach 1945-1970, Kraków 1995, aneks nr 3.

${ }^{74}$ Informacja o przebiegu orzecznictwa... w IV kwartale 1962 r., op. cit., s. 56.

${ }^{75}$ Notatka dot. działalności... w 1967 r., op. cit., s. 16. 
nie zamieszczono wzmianki o przepadku ofiar pochodzących z nielegalnych zbiórek $^{76}$. Brak tych informacji pozwala przypuszczać, że zabezpieczone przez organy ścigania kwoty były niewielkie.

Przepadek orzekano nie tylko w stosunku do zebranych ofiar pieniężnych, dotykał on także uzyskanych podczas zbiórek prowadzonych wśród mieszkańców wsi ofiar w naturze. Oprócz orzekania przepadku zajętych przez organy ścigania jaj kurzych, kwestionowano także zebrane na potrzeby klasztorów i seminariów duchownych płody rolne. Ilość ziemiopłodów ulegających przepadkowi zależała od skali zaangażowania organizatorów oraz zasięgu terytorialnego zbiórki. Zbierający ofiary wśród chłopów na potrzeby seminarium duchownego w Płocku administrator jednej z parafii powiatu Lipno otrzymał $500 \mathrm{~kg}$ ziemniaków, za co wymierzono mu grzywnę w wysokości 1000 zł połączoną z przepadkiem uzyskanych ofiar ${ }^{77}$. Z kolei grupa księży z powiatu nowotarskiego zebrała na potrzeby seminarium duchownego i Klasztoru Karmelitów w Krakowie około 9 ton ziemniaków, które zostały zakwestionowane przez MO podczas transportu do Krakowa. Przepadek orzeczono jedynie wobec trzeciej części zajętych ziemniaków, gdyż przed kolegium obwinieni zdołali udokumentować, iż pozostała część ziemiopłodów została przez nich zakupiona. Dwóch spośród czterech postawionych przed kolegium księży uznano winnymi zorganizowania nielegalnej zbiórki i ukarano stosunkowo wysokimi grzywnami - od 800 do $1200 \mathrm{zt}^{78}$. O ile w tej sprawie kolegium orzekło przepadek części zajętych ofiar, to zdarzały się przypadki zajmowania całości ziemiopłodów znajdujących się w gospodarstwie księdza, chociaż według wyjaśnień obwinionego część z nich stanowiła jego własność. Sytuacja taka miała miejsce w 1961 r. w powiecie jasielskim, gdzie kolegium powiatowe „ukarało ks. Kawulę grzywną za zorganizowanie zbiórki publicznej oraz orzekło przepadek zebranego nielegalnie zboża nie ustosunkowując się do wyjaśnień ukaranego, że część zboża nie pochodziła ze zbiórki”79. Dosyć surowo potraktowano także rekrutujących się z tzw. „aktywu przykościelnego” świeckich organizatorów zbiórki ziemiopłodów przeznaczonych na utrzymanie klasztoru Kamedułów w Bielenach koło Krakowa. Zebrana w trakcie tej zbiórki ilość ziemiopłodów nie była duża, gdyż organy ścigania zakwestionowały $1450 \mathrm{~kg}$ ziemniaków, $100 \mathrm{~kg}$ brukwi, 30 kg kapusty oraz $50 \mathrm{~kg}$ jęczmienia. Kolegium w Nowym Targu orzekło przepadek zajętych ziemiopłodów, a przeprowadzający zbiórkę chłopi zostali ukarani grzywnami w wysokości 750 i 850 zł $^{80}$.

${ }^{76}$ Notatka dot. działalności... w 1969 r., op. cit., s. 140 oraz Notatka dot. działalności... w 1970 r., op. cit., s. 152-153.

${ }^{77}$ Notatka w sprawie zgromadzeń... za I kwartał 1963 r., op. cit., s. 78.

${ }^{78}$ Sprawozdanie cyfrowe, op. cit., s. 36.

${ }^{79}$ Sprawozdanie z przebiegu orzecznictwa, op. cit., s. 9.

${ }^{80}$ Sprawozdanie cyfrowe, op. cit., s. 36-37. 
5. Spośród poszczególnych rodzajów nielegalnych zbiórek na cele religijne ze szczególną zaciętością zwalczano zbiórki na prowadzenie punktów katechetycznych. Wynikało to z faktu, iż zapoczątkowany w 1961 r. konflikt wokół rejestrowania i kontroli punktów katechetycznych stanowił jeden z głównych punków spornych w stosunkach państwo-Kościół okresu gomułkowskiego ${ }^{81}$. W ramach programu laicyzacji życia publicznego władze usunęły religię ze szkół, co spowodowało przeniesienie tych zajęć do organizowanych przez parafie punktów katechetycznych, które podlegały obowiązkowi rejestracji w inspektoratach oświaty ${ }^{82}$. Z tytułu prowadzenia punktów katechetycznych administratorzy parafii mieli otrzymywać wynagrodzenie ${ }^{83}$. Wymóg prowadzenia nauki religii w kontrolowanych przez władze punktach katechetycznych spotkał się ze sprzeciwem Episkopatu, wobec czego zdecydowana większość proboszczów odmówiła podpisania umów o pracę w punktach katechetycznych ${ }^{84}$.

W celu skłonienia księży do zarejestrowania punktów katechetycznych Departament Społeczno-Administracyjny MSW w tajnym okólniku z 2 marca 1962 r. skierował do podległego aparatu terenowego zalecenie, aby „w sposób zdecydowany zwalczać wszelkie formy zbiórek pieniędzy na cele prowadzenia punktów katechetycznych"85. Zbiórki były przeprowadzane z reguły przez osoby świeckie, które przy okazji ukarania grzywną informowano o korzyściach wynikających $\mathrm{z}$ finansowania przez państwo zarejestrowanych punktów katechetycznych. Miało to na celu „uwolnienie rodziców posyłających dzieci do punktów katechetycznych od wszelkich zbiórek pieniężnych i w naturze" ${ }^{86}$. Pieniądze zbierano $\mathrm{z}$ reguły na opłacenie katechety ${ }^{87}$, pokrycie kosztów przewozu katechety furmanką ${ }^{88}$, czy też „na wyposażenie i opał dla punktu katechetycznego", jak to miało miejsce w przypadku zbiórki przeprowadzonej w powiecie Brzesko przez „dwie świeckie aktywistki przykościelne” ${ }^{\text {. }}$

W ramach ograniczania zakresu budownictwa sakralnego represjonowano osoby przeprowadzające bez zezwolenia zbiórki na budowę kościoła, czy też

${ }^{81}$ A. Dudek, Państwo, op. cit., s. 91-92.

${ }^{82}$ Zarządzenie Ministra Oświaty w sprawie prowadzenia punktów katechetycznych, „Dziennik Urzędowy Ministerstwa Oświaty" 1961, nr 10, poz. 124.

${ }^{83}$ W. Makowski, Szkoła świecka a wolność sumienia, „Zagadnienia Karno-Administracyjne” 1961, nr 5, s. 34-35.

${ }^{84}$ A. Dudek, Państwo, op. cit., s. 92.

${ }^{85}$ Pismo dyrektora Dep. Spot.-Adm. H. Chmielewskiego do wszystkich, USW PWRN z 2 III 1962 r., cyt. za: A. Dudek, Państwo, op. cit., s. 151.

${ }^{86}$ Pismo dyrektora Departamentu Społeczno-Administracyjnego MSW H. Chmielewskiego z dnia 14 czerwca 1963 r. do ob. Marianny Sułeckiej, AAN UdsW 71/42, s. 130.

${ }^{87}$ Notatka w sprawie zgromadzeń... za I kwartał 1963 r., op. cit., s. 77.

${ }^{88}$ Sprawozdanie cyfrowe, op. cit., s 35.

${ }^{89}$ Ibidem. 
na remonty obiektów sakralnych. Przeważały zbiórki na remonty istniejących obiektów, gdyż restrykcyjna polityka wydziałów budownictwa i architektury prezydiów rad narodowych $\mathrm{w}$ zakresie wydawania pozwoleń budowlanych zahamowała do końca lat sześćdziesiątych rozwój budownictwa sakralnego. Jeżeli już miały miejsce zbiórki na budowę kościołów, to spotykały się one ze zdecydowana reakcją ze strony aparatu spraw wewnętrznych. Przykładem może być zbiórka na budowę kościoła przeprowadzona na terenie powiatu Przasnysz, której świecki organizator został ukarany grzywną 1500 zł, połączoną $\mathrm{z}$ orzeczeniem przepadku uzyskanych pieniędzy ${ }^{90}$. Surowo potraktowano także „świecka aktywistkę" zbierającą wśród mieszkańców wsi pieniądze na ogrodzenie krzyża przydrożnego, gdyż została wobec niej orzeczona grzywna $1300 \mathrm{z}^{91}$.

W przypadku zbiórek na odnowienie istniejących obiektów sakralnych wysokości grzywien były zróżnicowane w zależności od stopnia zaangażowania organizatorów i okoliczności sprawy. Brak sukcesu w postaci zajęcia przez organy ścigania pochodzących z nielegalnej zbiórki funduszy rekompensowano orzekaniem surowych grzywien, na co wskazuje przykład z terenu powiatu Wadowice. Jesienią 1963 r. „5 osobowa grupa aktywu przykościelnego przeprowadziła systemem domokrążnym zbiórkę na odnowienie kaplicy", przy czym „zebranych pieniędzy nie zdołano zabezpieczyć do przepadku”. Dwóch najbardziej aktywnych organizatorów zbiórki ukarano grzywnami powyżej tysiąca złotych, w przypadku jednego $\mathrm{z}$ nich była to grzywna w maksymalnym wymiarze $^{92}$. W przypadku zajęcia funduszy pochodzących $\mathrm{z}$ nielegalnej zbiórki kary nie były wysokie, na co wskazuje sprawa zbiórki na odnowienie kościoła $\mathrm{w}$ jednej $\mathrm{z}$ parafii powiatu Leszno. Organizatorów tej zbiórki ukarano grzywnami nie przekraczającymi tysiąca złotych, przy jednoczesnym przepadku pochodzących ze zbiórki 6 tys. $\mathrm{z}^{193}$. Stosunkowo łagodną karę - grzywnę $300 \mathrm{zł}$ - wymierzono gospodarzowi jednej ze wsi powiatu wrocławskiego przeprowadzającemu zbiórkę na remont kościoła, gdyż „organy ścigania zdołały zająć większą część zebranych ofiar, których miejscowy proboszcz nie zdążył jeszcze wydatkować" ${ }^{94}$.

W odniesieniu do pozostałych rodzajów zbiórek represja karno-administracyjna nie była surowa, gdyż zbiórki te nie miały bezpośredniego związku z głównymi punktami zapalanymi w stosunkach państwo-Kościół. Były to

\footnotetext{
${ }^{90}$ Sprawozdanie opisowe... za II kwartał 1964 r., op. cit., s. 238.

${ }^{91}$ Ibidem.

${ }^{92}$ Dwóch pozostałych organizatorów zbiórki ukarano grzywnami w wysokości 800 i 500 zł, w stosunku do jednej osoby orzeczono jedynie naganę. Sprawozdanie cyfrowe, op. cit., s. 36.

${ }^{93}$ Wyciag z Biuletynu Tygodniowego MSW nr 31 z dn. 2 VIII 1963 r., AAN UdSW 71/42, s. 135.

${ }_{94}$ Notatka w sprawie zgromadzeń... za I kwartał 1963 r., op. cit., s. 78.
} 
głównie zbiórki na cele religijne o tradycyjnym charakterze, np. w III kwartale 1963 r. spośród „114 spraw o nielegalnie przeprowadzone zbiórki na cele religijne, najliczniejszą grupę stanowiły zbiórki ofiar na zakup mszy w intencji deszczu" ${ }^{95}$. Kolegia karały także osoby przeprowadzające zbiórki pieniężne na kwiaty celem udekorowania grobu Pańskiego lub ołtarza, ale orzekane grzywny nie były wysokie ${ }^{96}$. Wierni organizowali także zbiórki na cele związane $\mathrm{z}$ funkcjonowaniem swojej parafii, $\mathrm{w}$ tym na opłacenie składki obowiązkowego ubezpieczenia PZU budynków parafialnych ${ }^{97}$, czy też zakup samochodu dla księdza $^{98}$. Poświęcenie parafian wyrażało się także w organizowaniu zbiórek na pokrycie kar grzywny orzeczonych wobec księży zarówno przez kolegia, jak i przez organy administracji $\mathrm{w}$ ramach postępowania przymusowego ${ }^{99}$. $\mathrm{Za}$ przykład może posłużyć zbiórka pieniężna przeprowadzona przez „7 osobową grupę świeckiego aktywu przykościelnego" na wykup krowy proboszcza sprzedanej przez organ finansowy na licytacji. Licytacja miała na celu ściągnięcie należności od miejscowego proboszcza ukaranego w postępowaniu przymusowym przez organ oświaty za prowadzenie niezarejestrowanego punktu katechetycznego ${ }^{100}$.

6. Stosunek władz komunistycznych okresu gomułkowskiego do zbiórek publicznych na cele religijne był pochodną polityki państwa wobec Kościoła katolickiego. Początki rządów Gomułki przynoszą złagodzenie stosunków państwo-Kościół, który wykorzystał krótkotrwałą liberalizację systemu do wzmocnienia swojej pozycji w społeczeństwie. Realizacja programu Wielkiej Nowenny oznaczała rozszerzenie zakresu pracy duszpasterskiej oraz rozwój budownictwa sakralnego, na co potrzebne były fundusze ze zbiórek publicznych. Polityka władz w zakresie udzielania zezwoleń i respektowania wyłączenia spod tego wymogu zbiórek na tradycyjne cele religijne w latach 1957-1958 była stosunkowo liberalna. Zmiana nastąpiła wraz podjęciem przez Gomułkę w połowie 1958 r. ofensywy antykościelnej, której celem było ograniczenie roli Kościoła jedynie do wykonywania tradycyjnych obrzędów religijnych. Zakwestionowanie założeń programu Wielkiej Nowenny pociągnęło za sobą uderzenie w podstawy majątkowe Kościoła, czego przeja-

${ }^{95}$ Informacja o przebiegu orzecznictwa... w III kwartale 1963 r., op. cit., s. 113.

${ }^{96}$ Gospodarza zbierającego pieniądze na kwiaty do grobu w kościele (wysokości zebranej sumy nie ustalono) ukarano grzywną 500 zł. Dwie rencistki, które zebrały na kwiaty do kościoła kwotę 360 zł i przekazały ją następnie miejscowemu księdzu, zostały ukarane grzywną po 300 zł każda. Sprawozdanie opisowe... za II kwartał 1964 r., op. cit., s. 238-239.

${ }^{97}$ Ibidem, s. 238.

${ }^{98}$ Notatka w sprawie zgromadzeń... za I kwartał 1963 r., op. cit., s. 78.

${ }^{99}$ Ibidem, s. 77.

${ }^{100}$ Sprawozdanie cyfrowe, op. cit., s. 35. 
wem było rygorystyczne przestrzeganie obowiązku uzyskania zezwolenia na przeprowadzanie wszelkiego rodzaju zbiórek poza obrębem miejsc kultu religijnego. Zaskoczenie wywołane nagłą zmianą postawy władz skutkowało znaczącym wzrostem liczby wniosków o ukaranie organizatorów nielegalnych zbiórek oraz zajmowaniem przez organy ścigania dużych kwot zebranych pieniędzy. Sukcesy władz mierzone wartością zajętych funduszy były jednak krótkotrwałe, gdyż organizatorzy zbiorek zaczęli przeprowadzać je w sposób bardziej zakamuflowany. Efektem był gwałtowny spadek wykrywalności nielegalnych zbiórek i znaczne zmniejszenie wartości kwestionowanych ofiar. W takiej sytuacji nawet wysokie grzywny orzekane przez kolegia nie odnosiły skutku, gdyż jak przyznano w 1961 r. „wobec zajmowania niewielkich sum pieniędzy kler płaci orzekane grzywny $\mathrm{z}$ zebranych kwot, pozostawiając sobie niejednokrotnie poważne środki na działalność kościoła pochodzące z nielegalnych zbiórek"101.

Chociaż podejmowane przez władze działania nie pociągały za sobą istotnej dolegliwości finansowej dla proboszczów, to z przyczyn ideologicznych restrykcyjna polityka $\mathrm{w}$ zakresie zbiórek publicznych na cele religijne była kontynuowana do końca lat sześćdziesiątych. Komuniści upatrywali w niej instrument publicznej rywalizacji z Episkopatem o sprawowanie rządów nad duszami Polaków, co należy uznać za przejaw głupoty typowej dla władz gomułkowskich. Godne podkreślenia jest zaangażowanie katolików świeckich w organizowanie i prowadzenie zbiórek na cele religijne, gdyż to oni przejęli na swoje barki główny ciężar pozyskiwania w ten sposób funduszy na działalność Kościoła. Pomimo groźby ukarania wysokimi grzywnami, wierni wspierali swoich duszpasterzy $\mathrm{w}$ pozyskiwaniu środków materialnych, dzięki czemu Kościół był w stanie wypełnić zadania postawione przed nim w związku z akcją Wielkiej Nowenny.

Reasumując należy stwierdzić, że działania władz, mające na celu odcięcie duchowieństwa od funduszy pochodzących ze zbiórek publicznych, tylko w niewielkim stopniu naruszyły podstawy majątkowe Kościoła, przez co nie stanowiły istotnej przeszkody w procesie jego dynamicznego rozwoju w okresie gomułkowskim $^{102}$.

\footnotetext{
${ }^{101}$ Notatka dot. działalności... w 1967 r., op. cit., s. 16.

${ }^{102}$ A. Dudek, R. Gryz, Komuniści, op. cit., s. 274.
} 